\section{Inoculating Acacia koa with Bradyrhizobium and Applying Fertilizer in the Nursery: Effects on Nodule Formation and Seedling Growth}

\author{
R. Kasten Dumroese ${ }^{1}$ \\ USDA Forest Service, Rocky Mountain Research Station, 1221 South Main \\ Street, Moscow, ID 83843-4211 \\ Douglass F. Jacobs \\ Hardwood Tree Improvement and Regeneration Center, Department of Forestry \\ and Natural Resources, Purdue University, West Lafayette, IN 47907
}

Anthony S. Davis

Center for Forest Nursery and Seedling Research, College of Natural Resources, University of Idaho, Moscow, ID 83844

Additional index words. container nursery, controlled-release fertilizer, nitrogen use efficiency, nitrogen-fixing bacteria, forest restoration

\begin{abstract}
Restoration of Acacia koa A. Gray (koa) forests on degraded sites in Hawaii is important for conservation of rare, endemic plants and animals and is often accomplished by planting nursery-grown seedlings. To be successful after outplanting, koa seedlings must access sufficient nutrients from the soil and outcompete other vegetation. Forming symbiotic associations with nitrogen-fixing microorganisms may help alleviate inherent nutrient deficiencies found on volcanic sites, but interactions between inoculation and fertilization during production of koa seedlings are not well studied. Under operational nursery conditions, we fertilized koa seedlings at six controlled-release fertilizer (CRF) rates (ranging from 0 to $11.9 \mathrm{~kg} \cdot \mathrm{m}^{-3}$ Osmocote Plus $15 \mathrm{~N}-9 \mathrm{P}-12 \mathrm{~K}$ ), which were also either inoculated with a locally collected source of nitrogen-fixing Bradyrhizobium spp. or not. Fertilized seedlings were significantly larger than the control; on average, fertilized seedlings were $300 \%$ taller and had $180 \%, 700 \%$, and $350 \%$ more root-collar diameter, shoot biomass, and root biomass, respectively. Nitrogen $(N)$ concentration was $23 \%$ to $\mathbf{1 1 9 \%}$ greater in fertilized seedlings than nonfertilized seedlings. Inoculation with Bradyrhizobium had no significant affect on seedling characteristics except for root $\mathbf{N}$ concentration, which was $8 \%$ higher for inoculated seedlings. Fertilizer rate and inoculation interacted to significantly affect nodule number and nodule biomass/seedling. With inoculation, we observed an increase in nodule number (16.5 to 25.5$)$ and biomass $\left(5.8 \mathrm{mg}\right.$ to $11.7 \mathrm{mg}$ ) with fertilizer rate up to $4.7 \mathrm{~kg} \cdot \mathrm{m}^{-3}$ but a decline to nearly zero at the highest rates. Without inoculation, nodule formation was scarce (3.2 nodules/seedling or less) and only observed when CRF was $2.3 \mathrm{~kg} \cdot \mathrm{m}^{-3}$ or less. Our results suggest that high rates of fertilization and successful nodulation are not mutually exclusive nursery practices. Concurrent use of fertilization and inoculation in the nursery may provide opportunity to produce larger seedlings that have high potential to reduce the time needed to achieve canopy closure and thereby help achieve restoration objectives.
\end{abstract}

Received for publication 17 Dec. 2008. Accepted for publication 13 Jan. 2009.

This project was supported by the USDA Forest Service Center for Reforestation, Nurseries, and Genetics Resources; Purdue University; the University of Idaho Center for Forest Nursery and Seedling Research; and the Hawaii Division of Forestry and Wildlife.

We thank Ian Shigematsu, Mee-Sook Kim, Joanne Tirocke, and Amy Ross-Davis for their valuable contributions to the experiment.

${ }^{1}$ To whom reprint requests should be addressed; e-mailkdumroese@fs.fed.us. trees can enhance species richness (Parrotta, 1992). For these reasons, interest in planting koa has increased (Pejchar and Press, 2006), especially to renew native forest bird habitat (Horiuchi and Jeffrey, 2002).

On disturbed tropical sites, planting tree seedlings may accelerate forest recovery, but success can be hampered by grass competition, poor soil nutrient availability, changes in soil conditions, harsh microclimates, and a lack of symbiotic microorganisms (Denslow et al., 2006; Holl et al., 2000; Horiuchi and Jeffrey, 2002; Scowcroft and Jeffrey, 1999) with grass competition paramount (Holl et al., 2000). Many sites on the island of Hawaii are infested with the introduced invasive Pennesitum clandestinum (kikuyu grass) (Motooka et al., 2003); this rhizomatous grass forms dense, thick mats that impede artificial regeneration of koa forests (Jeffrey and Horiuchi, 2003). In temperate forest regeneration, large nursery-grown seedlings are preferred for outplanting on sites where competition is severe because of improved performance compared with smaller cohorts (Jobidon et al., 1998; South and Mitchell, 1999). For restoration of koa forests and their important understory plants needed by endangered species, more rapid initial seedling growth gained by outplanting larger stock types may lead to quicker canopy closure. Canopy closure initiates the desired process of reducing competitor biomass, making soil chemical properties more like those found in original forests and enhancing establishment of desired understory species (Scowcroft et al., 2004; Scowcroft and Jeffrey, 1999).

Volcanic soils are inherently deficient in nitrogen (N) (Vitousek and Farrington, 1997) and $\mathrm{N}$ availability is a primary factor limiting seedling growth (Nambiar and Sands, 1984). Koa, however, forms a symbiotic relationship with Bradyrhizobium spp. (Allen and Allen, 1936), widespread N-fixing bacteria found in tropical soils (Graham and Hubbell, 1975; Nakao and Kitayama, 1996; Woomer et al., 1988), and this partnership results in abundant soil $\mathrm{N}$ availability (Idol et al., 2007; Scowcroft et al., 2004). Inoculating seeds or nursery stock of other Acacia species with rhizobial inoculants has been shown to increase survival (Thrall et al., 2005) and biomass production on field sites (Herrera et al., 1993; Lal and Khanna, 1996). One reason for such improvement is that bacteria fix atmospheric $\mathrm{N}$ that is available to seedlings during the critical establishment phase, mitigating poor soil nutrient availability that reduces tropical forest regrowth (Aide and Cavelier, 1994). It is well known, however, that increasing levels of mineral nutrition provided by fertilization decrease nodule formation and function (Goicoechea et al., 2004; Patreze and Cordeiro, 2004). Determining fertilization regimes that promote production of larger seedlings that are better able to outcompete associated vegetation, while concurrently providing seedlings with symbionts needed after outplanting, could reduce nursery production time. We hypoth- 
esized that Bradyrhizobium nodule number and biomass on container Acacia koa seedlings would decrease with increasing fertilizer rates and that at some level, fertilization would exclude nodule formation. Our objective was to ascertain the effects of increasing fertilizer rates on Bradyrhizobium nodule formation and biomass under operational nursery conditions.

\section{Materials and Methods}

In early Dec. 2006, following the basic methods of Wilkinson and Elevitch (2003), we collected $\approx 100$ Bradyrhizobium spp. nodules from koa roots (roots were traced back to the parent plant) at Hakalau Forest National Wildlife Refuge on the island of Hawaii (long. $19^{\circ} 49^{\prime} 15^{\prime \prime} \mathrm{N}$, lat. $155^{\circ} 19^{\prime} 48^{\prime \prime}$ $\mathrm{W} ; 1941 \mathrm{~m})$, rinsed them clean of soil, blended them in $1 \mathrm{~L}$ of distilled water, and refrigerated the solution in an air-tight container at $\approx 4{ }^{\circ} \mathrm{C}$. Concurrently, following the general guidelines of Rice and Olsen (1993), we diluted the slurry, plated samples on a yeast extract mannitol agar media $(\mathrm{pH} 6.8$ to 7.2), incubated the inverted petri plates for 7 d at $30^{\circ} \mathrm{C}$, and then counted colonies. In early Jan. 2007 at the Hawaii Division of Forestry and Wildlife Kamuela (Waimea) State Tree Nursery, just south of Kamuela on the island of Hawaii (long. $20^{\circ} 00^{\prime} 24^{\prime \prime} \mathrm{N}$, lat. $155^{\circ} 40^{\prime} 38^{\prime \prime}$ W), we transplanted germinating (7 d after hot water soak) koa seeds collected at Hakalau into Deepot D-16 containers $\left(262 \mathrm{~cm}^{3} ; 5\right.$ $\mathrm{cm}$ diameter and 18-cm depth; Stuewe and Sons, Inc., Corvallis, OR) filled with a two parts Sphagnum peatmoss (Pro-Mix; Premier Horticulture, Dorval, Quebec, Canada) to one part perlite $(\mathrm{v}: \mathrm{v})$ medium containing one of six levels of controlled-release fertilizer [0, 2.3, 4.7 (the "medium" rate on the fertilizer label), 7.1, 9.5, and $11.9 \mathrm{~kg} \cdot \mathrm{m}^{-3}$ Osmocote Plus $^{\circledR} 15 \mathrm{~N}-9 \mathrm{P}-12 \mathrm{~K}$ (5- to 6-month longevity at $21{ }^{\circ} \mathrm{C}$; Scotts Co., Marysville, $\mathrm{OH}$ )]. These incorporation rates reflect the volume of the medium after it was released from the bag. Within $2 \mathrm{~d}$ of transplanting, we diluted the 1 $\mathrm{L}$ of inoculum into $6 \mathrm{~L}$ of tap water, and inoculated half of the seedlings in each fertilizer treatment with $10 \mathrm{~mL}$ of solution per seedling to provide $\approx 10^{7}$ colony-forming units/seedling. The other half was not inoculated. Thus, our experiment was a 6 (fertilizer levels) $\times 2$ (inoculation levels) $\times 4$ (replications) randomized complete block split-plot design with fertilizer as the whole-plot factor and inoculation as the split-plot factor. Each fertilizer-inoculation-replicate whole plot consisted of a tray containing 50 D-16 containers; one half of each tray was inoculated (1200 total seedlings). Trays were randomly positioned (with $\approx 15 \mathrm{~cm}$ separating each tray) on benches in an outdoor growing area.

In Apr. 2007, we randomly harvested five plants from the centermost containers (avoiding seedlings growing on the perimeters of the replications to avoid edge effects) from each fertilizer-inoculum-replicate combination (120 sampled seedlings) and gently washed root systems free of medium. We measured rootcollar diameter and shoot height. Nodules were counted and harvested. For each seedling, we observed three nodules in crosssection using a $10 \times$ hand lens; starting at the midpoint of the root plug, we excised the first proximal, acropetal nodule, then the first proximal, basipetal nodule, repeating the sequence until three nodules (if available) were collected. Shoots, roots, and nodules were separated and oven-dried $72 \mathrm{~h}$ at $65{ }^{\circ} \mathrm{C}$ for biomass determination. Shoots and roots for each fertilizer-inoculation combination were pooled by replicate, ground to pass a 0.04- $\mathrm{mm}$ mesh, and analyzed with a LECO600 (LECO Corp., St. Joseph, MI). Nitrogen use efficiency was calculated by dividing the nutrient content (tissue concentration $\times$ biomass) of the entire seedling by the total amount of $\mathrm{N}$ applied to the seedling.

Analysis of variance using the SAS (SAS Inc., Cary, NC) PROC MIXED $(\alpha=0.05)$ procedure was used to examine the effects of our predictor variables on eight koa seedling response variables: height $(\mathrm{cm})$, root-collar diameter $(\mathrm{mm})$, shoot dry weight $(\mathrm{g})$, root dry weight $(\mathrm{g})$, number of nodules, total nodule weight $(\mathrm{mg})$, and nitrogen $\left(\mathrm{g} \cdot \mathrm{kg}^{-1}\right)$ within shoots and roots (pooled across seedlings within treatment replicates; $n=5$ ). Comparisons within predictor variables were analyzed using least-squares means of fixed effects with a multiple comparison Tukey adjustment for the $P$ values. Because nodule data violated parametric assumptions, nodule number and biomass/seedling were log-transformed (adding 0.5 to each observation given the presence of zeros). Means and sEs reflect untransformed data.

\section{Results}

Fertilizer rate significantly affected every measured response variable (Tables 1 and 2). On average, fertilized seedlings had significantly larger heights $(300 \%)$, root-collar diameters $(180 \%)$, shoot biomass $(700 \%)$, and root biomass $(350 \%)$ than the control, but increasing fertilizer greater than 2.3 $\mathrm{kg} \cdot \mathrm{m}^{-3}$ did not significantly increase seedling size (Table 2). Tissue $\mathrm{N}$ concentrations, however, were significantly greater with increasing fertilizer rate (Table 2). The highest rate of controlled-release fertilizer (CRF) resulted in a $55 \%$ and $218 \%$ increase in root and shoot $\mathrm{N}$ concentration, respectively, compared with the nonfertilized control. Lack of a significant increase in seedling height, root-collar diameter, or total biomass in the presence of increasing $\mathrm{N}$ concentration for seedlings fertilized with greater than 2.3 $\mathrm{kg} \cdot \mathrm{m}^{-3}$ indicates luxury consumption (Table 2). Nitrogen use efficiency decreased with increasing rate of CRF; efficiency was $17 \%$ in the $2.3 \mathrm{~kg} \cdot \mathrm{m}^{-3} \mathrm{CRF}$ treatment compared with $9 \%$ in the $11.9 \mathrm{~kg} \cdot \mathrm{m}^{-3}$ treatment.

Although inoculation did not affect seedling size, it did significantly affect the number and biomass of nodules per seedling and root $\mathrm{N}$ concentration (Table 1 ). Nearly all nodules showed the pinkish red coloration of leghemoglobin, suggesting active $\mathrm{N}$ fixation. Inoculated seedlings had more $(11.5 \pm 1.9$ versus $0.7 \pm 0.3)$ nodules and greater nodule biomass/seedling $(4.9 \pm 0.9 \mathrm{mg}$ versus $0.5 \pm$ $0.2 \mathrm{mg}$ ) than noninoculated control seed-

Table 1. Sources of variation and $P$ values observed for Acacia koa seedlings inoculated with Bradyrhizobium, fertilized with six rates of controlled-release fertilizer, and grown 12 weeks in a container nursery.

\begin{tabular}{lcccrrrr}
\hline $\begin{array}{l}\text { Source of } \\
\text { variation }\end{array}$ & $\mathrm{Ht}$ & $\begin{array}{c}\text { Root-collar } \\
\text { diam }\end{array}$ & $\begin{array}{c}\text { Shoot } \\
\text { biomass }\end{array}$ & $\begin{array}{c}\text { Root } \\
\text { biomass }\end{array}$ & $\begin{array}{r}\text { Nodule } \\
\text { biomass }\end{array}$ & $\begin{array}{c}\text { Number of } \\
\text { nodules }\end{array}$ & $\begin{array}{r}\text { Shoot N } \\
\text { Root N }\end{array}$ \\
\hline Fertilization & $<0.0001$ & $<0.0001$ & 0.0003 & 0.0013 & 0.0003 & 0.0002 & $<0.0001$ \\
Inoculation & 0.7925 & 0.9240 & 0.6766 & 0.1391 & $<0.0001$ & $<0.0001$ & 0.1547 \\
Interaction & 0.8338 & 0.4864 & 0.7363 & 0.6411 & $<0.0001$ & $<0.0001$ & 0.0001 \\
\hline
\end{tabular}

Table 2. Means \pm SEs for morphological parameters of Acacia koa seedlings inoculated with Bradyrhizobium, fertilized with six rates of controlled-release fertilizer, and grown 12 weeks in a container nursery. ${ }^{z}$

\begin{tabular}{|c|c|c|c|c|c|c|}
\hline $\begin{array}{l}\text { Fertilizer } \\
\text { rate }\left(\mathrm{kg} \cdot \mathrm{m}^{-3}\right)\end{array}$ & $\mathrm{Ht}(\mathrm{cm})$ & $\begin{array}{l}\text { Root-collar } \\
\text { diam }(\mathrm{mm})\end{array}$ & $\begin{array}{c}\text { Shoot } \\
\text { biomass }(g)\end{array}$ & $\begin{array}{c}\text { Root } \\
\text { biomass (g) }\end{array}$ & $\begin{array}{l}\text { Shoot N } \\
\left(\mathrm{g} \cdot \mathrm{kg}^{-1}\right)\end{array}$ & $\begin{array}{l}\text { Root N } \\
\left(\mathrm{g} \cdot \mathrm{kg}^{-1}\right)\end{array}$ \\
\hline 0 & $6.8 \pm 0.2 \mathrm{a}$ & $1.91 \pm 0.03 \mathrm{a}$ & $0.20 \pm 0.01 \mathrm{a}$ & $0.14 \pm 0.01 \mathrm{a}$ & $17.6 \pm 0.9 \mathrm{a}$ & $17.3 \pm 0.6 \mathrm{a}$ \\
\hline 2.3 & $17.3 \pm 0.7 b$ & $3.07 \pm 0.09 \mathrm{~b}$ & $1.12 \pm 0.08 \mathrm{~b}$ & $0.48 \pm 0.03 b$ & $21.7 \pm 0.6 \mathrm{ab}$ & $19.2 \pm 0.5 \mathrm{ab}$ \\
\hline 4.7 & $18.8 \pm 0.7 b$ & $3.24 \pm 0.07 b$ & $1.22 \pm 0.07 \mathrm{~b}$ & $0.45 \pm 0.03 b$ & $27.5 \pm 2.9 \mathrm{~b}$ & $21.7 \pm 0.8 \mathrm{bc}$ \\
\hline 7.1 & $21.0 \pm 1.1 \mathrm{~b}$ & $3.38 \pm 0.12 b$ & $1.55 \pm 0.13 b$ & $0.50 \pm 0.04 b$ & $29.3 \pm 1.3 \mathrm{c}$ & $24.8 \pm 0.7 \mathrm{~cd}$ \\
\hline 9.5 & $23.1 \pm 1.1 \mathrm{~b}$ & $3.67 \pm 0.13 b$ & $1.69 \pm 0.12 b$ & $0.50 \pm 0.04 b$ & $37.4 \pm 2.3 \mathrm{~d}$ & $27.8 \pm 0.9 \mathrm{~d}$ \\
\hline 11.9 & $22.7 \pm 1.1 \mathrm{~b}$ & $3.76 \pm 0.12 b$ & $1.81 \pm 0.13 \mathrm{~b}$ & $0.56 \pm 0.05 \mathrm{~b}$ & $38.5 \pm 1.6 \mathrm{~d}$ & $26.8 \pm 1.1 \mathrm{~d}$ \\
\hline
\end{tabular}

${ }^{\mathrm{z}}$ Means for each parameter with the same letter are not significantly different at $\alpha=0.05$. $\mathrm{n}=20$ for height, root-collar diameter, and biomass; $\mathrm{n}=4$ for $\mathrm{N}$ concentration. 


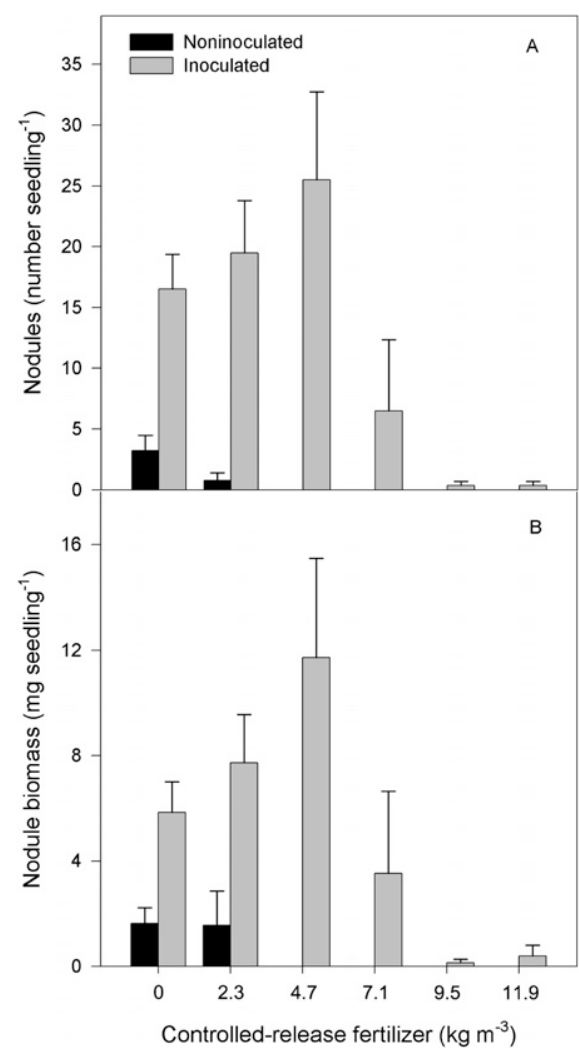

Fig. 1. Untransformed mean number of nodules (A) and total nodule biomass (B) of container Acacia koa seedlings 12 weeks after germination by controlled-release fertilizer and Bradyrhizobium treatments. Bars indicate SE of the means, $n=4$.

lings. Root $\mathrm{N}$ concentration of inoculated seedlings was $8 \%$ greater than control seedlings $(2.38 \% \pm 0.09$ versus $2.21 \% \pm 0.09)$.

Fertilizer and inoculation significantly interacted to affect nodule number and biomass/seedling (Table 1; Fig. 1). For both response variables, the pattern was similar. Noninoculated seedlings without fertilizer had few nodules $(3.2 \pm 1.3)$, those receiving $2.3 \mathrm{~kg} \cdot \mathrm{m}^{-3} \mathrm{CRF}$ had even fewer $(0.8 \pm 0.7)$, and those receiving greater than $2.3 \mathrm{~kg} \cdot \mathrm{m}^{-3}$ had none. Moreover, only $45 \%$ of the plants (nine of 20) in the control and 10\% (two of 20) of the plants in the $2.3 \mathrm{~kg} \cdot \mathrm{m}^{-3}$ rate formed nodules without inoculation; the remaining 109 noninoculated seedlings (91\%) lacked nodules. In contrast, nodules developed on inoculated seedlings across all six of the fertilizer treatments with a bell-shaped frequency distribution of increasing numbers of nodules (and more nodule biomass/seedling) from the nonfertilized control treatment (16.5 $\pm 2.8 ; 5.8 \pm 1.2 \mathrm{mg})$ up to $4.7 \mathrm{~kg} \cdot \mathrm{m}^{-3}(25.5 \pm$ $7.3 ; 11.7 \pm 3.8 \mathrm{mg}$ ) followed by a sharp decline from the $4.7 \mathrm{~kg} \cdot \mathrm{m}^{-3}$ fertilizer treatment to $11.9 \mathrm{~kg} \cdot \mathrm{m}^{-3}(0.4 \pm 0.4 ; 0.4 \pm 0.4 \mathrm{mg})$. When inoculated, the percentage of seedlings with nodules decreased from $95 \%$ to $70 \%$ as CRF rate increased from 0 to $4.7 \mathrm{~kg} \cdot \mathrm{m}^{-3}$ before dropping to $16 \%$ at $7.1 \mathrm{~kg} \cdot \mathrm{m}^{-3}$ and just $5 \%$ at the two highest CRF rates. For seedlings with nodules, mean biomass/nodule was 0.5 and $2.1 \mathrm{mg}$ for noninoculated seedlings receiving 0 and $2.3 \mathrm{~kg} \cdot \mathrm{m}^{-3}$, respec- tively; for inoculated seedlings, mean biomass/nodule was $0.4,0.4,0.4,0.7,0.4$, and 1.1 as CRF increased from 0 to $11.9 \mathrm{~kg} \cdot \mathrm{m}^{-3}$.

\section{Discussion}

Many studies stress the importance of inoculating seedlings with the correct symbiont microorganism to achieve optimum nodule formation (Galiana et al., 1990; Thrall et al., 2000; Valladares et al., 2002; Woldemeskel and Sinclair, 1998). In our study, inoculating nursery seedlings with a simple slurry of ground Bradyrhizobium nodules collected from koa trees yielded subsequently high levels of nodulation, akin to work by Villar-Salvador et al. (2008). We also observed a few sporadic nodules in the absence of inoculation, similar to that reported by Lesueur and Duponnois (2005) on another Acacia species. These nodules were most commonly found on nonfertilized, noninoculated seedlings that, in their nutrient-stressed status, may have had a higher proclivity for infection. This response is similar to that of nonfertilized but inoculated seedlings, which also had the highest rates of nodulation. Because seedlings were grown in an outdoor compound under operational cultural conditions, contamination of noninoculated seedlings may have occurred by windborne deposition of soil particles or through transfer by nursery workers, insect vectors, or precipitation/irrigation events.

Low doses of fertilizer may improve nodule formation by $\mathrm{N}$-fixing bacteria (Goicoechea et al., 2004; Röhm and Werner, 1991). In our study using CRF, the lowest rate of fertilizer $\left(2.3 \mathrm{~kg} \cdot \mathrm{m}^{-3}\right)$, which was equal to the "low" label rate, yielded the same nodule number and nodule biomass/ seedling as the nonfertilized control, although plant biomass increased by $470 \%$. Moreover, doubling the rate of CRF appeared to have no impact on nodule formation or nodule biomass although seedling biomass was not statistically increased. Although we did not quantify nitrogenase activity directly, we observed that most nodules on fertilized seedlings showed the apparent presence of leghemoglobin.

The benefits of improved growth with fertilizer as well as reduction or hindrance of $\mathrm{N}$ fixation by excessive $\mathrm{N}$ application to tree seedlings are well described (Mrema et al., 1997; Valladares et al., 2002). Our results indicate that fertilization rate is a more rapid method for obtaining target plant size in the nursery than the sole use of Bradyrhizoibum inoculum but that it is possible to produce well-fertilized seedlings with a complement of nodules. Villar-Salvador et al., (2008) found that seedlings given high rates of fertilizer in the nursery had greater size, root growth capacity, photosynthetic rates, and $\mathrm{N}$ concentrations than seedlings given low rates of fertilizer either with or without rhizobial inoculation. For koa in our study, robust rates of fertilization (i.e., the "high" rate on the fertilizer label; $\approx 7.1 \mathrm{~kg} \cdot \mathrm{m}^{-3}$ ) still allowed nodule formation and color consistent with the presence of leghemoglobin. Seedlings treated with the "low" label rate were $\approx 68 \%$ taller with $52 \%$ more root-collar diameter than the traditional "dibble tube" $\left(50 \mathrm{~cm}^{3} ; 2.5-\mathrm{cm}\right.$ diameter and $12-\mathrm{cm}$ depth) seedlings currently used for restoration plantings on the island of Hawaii (Walters, 1981), even though dibble tube seedlings were grown at the "medium" label rate and all seedlings had similar production times in the nursery.

Our $2.3 \mathrm{~kg} \cdot \mathrm{m}^{-3} \mathrm{CRF}$ rate was sufficient for balancing koa seedling size and nutrient content with Bradyrhizobium inoculation and nodule biomass production within the same production period as the current operational standard. Future work on outplanting sites is needed to validate whether larger, well-fertilized koa seedlings with high levels of nodules have increased survival and growth compared with seedlings fertilized to maximize biomass and nutrient content regardless of effects on nodulation.

\section{Literature Cited}

Aide, T.M. and J. Cavelier. 1994. Barriers to lowland tropical forest restoration in the Sierra Nevada de Santa Marta, Columbia. Restor. Ecol. 2:219-229.

Allen, O.N. and E.K. Allen. 1936. Root nodule bacteria of some tropical leguminous plants: I. Cross inoculation studies with Vigna sinensis L. Soil Sci. 42:61-77.

Cole, T.G., R.S. Yost, R. Kablan, and T. Olsen. 1996. Growth potential of twelve Acacia species on acid soils in Hawaii. For. Ecol. Mgt. 80:175-196.

Denslow, J.S., A.L. Uowolo, and R.F. Hughes. 2006. Limitations to seedling establishment in a mesic Hawaiian forest. Oecologia 148: $118-128$.

Galiana, A., J. Chaumont, H.G. Diem, and Y.R. Dommergues. 1990. Nitrogen-fixing potential of Acacia mangium and Acacia auriculiformis seedlings inoculated with Bradyrhizobium and Rhizobium spp. Biol. Fertil. Soils 9:261-267.

Goicoechea, N., S. Merino, and M. Sánchez-Díaz. 2004. Management of phosphorus and nitrogen fertilization to optimize Anthyllis-GlomusRhizobium symbiosis for revegetation of desertified semiarid areas. J. Plant Nutr. 27:13951413.

Graham, P. and D. Hubbell. 1975. LegumeRhizobium relationships in tropical agriculture. In: Tropical forages in livestock production systems. American Society of Agronomy. Special Pub. 24:9-21.

Herrera, M.A., C.P. Salamanca, and J.M. Barea. 1993. Inoculation of woody legumes with selected arbuscular mycorrhizal fungi and rhizobia to recover desertified Mediterranean ecosystems. Appl. Environ. Microbiol. 59: 129-133.

Holl, K.D., M.E. Loik, E.H.V. Lin, and I.A. Samuels. 2000. Tropical montane forest restoration in Costa Rica: Overcoming barriers to dispersal and establishment. Restor. Ecol. 8:339-349.

Horiuchi, B. and J. Jeffrey. 2002. Native plant propagation and habitat restoration at Hakalau Forest National Wildlife Refuge, Hawaii. Natl. Proc. For. Conservation Nursery Assoc.-1999, 2000, 2001. USDA For. Serv. Proc. RMRS-P-24 p. 233. 
Idol, T.W., P.J. Baker, and D.F. Meason. 2007. Indicators of forest ecosystem productivity and nutrient status across precipitation and temperature gradients in Hawaii. J. Trop. Ecol. 23:693-704.

Jeffrey, J. and B. Horiuchi. 2003. Tree planting at Hakalau Forest National Wildlife Refuge-The right tool for the right stock type. Native Plants J. 4:30-31.

Jobidon, R., L. Charette, and P.Y. Bernier. 1998. Initial size and competing vegetation effects on water stress and growth of Picea mariana (Mill.) BSP seedlings planted in three different environments. For. Ecol. Mgt. 103:293-305.

Lal, B. and S. Khanna. 1996. Long term field study shows increased biomass production in tree legumes inoculated with Rhizobium. Plant Soil 184:111-116.

Lesueur, D. and R. Duponnois. 2005. Relations between rhizobial nodulation and root colonization of Acacia crassicarpa provenances by an arbuscular mycorrhizal fungus, Glomus intraradices Schenk and Smith or an ectomycorrhizal fungus, Pisolithus tinctorius Coker \& Couch. Ann. For. Sci. 62:467-474.

Motooka, P., L. Castro, D. Nelson, G. Nagai, and L. Ching. 2003. Weeds of Hawaii's pastures and natural areas. College of Tropical Agric. and Human Resources, Univ. of Hawaii, Mānoa, HI.

Mrema, A.F., U. Granhall, and L. Sennerby-Forsse. 1997. Plant growth, leaf water potential, nitrogenase activity and nodule anatomy in Leucaena leucocephala as affected by water stress and nitrogen availability. Trees 12:42-48.

Nakao, P. and K. Kitayama. 1996. Distribution of Bradyrhizobium spp. and endemic leguminous tree Acacia koa along an altitudinal transect on the windward slope of Haleakala, Maui, Hawaii. Biotropica 28:400-403.

Nambiar, E.K.S. and R. Sands. 1984. Competition for water and nutrients in forests. Can. J. For. Res. 23:1955-1968.
Parrotta, J.A. 1992. The role of plantation forests in rehabilitating degraded tropical ecosystems. Ecosystems Environ. 41:115-133.

Patreze, C.M. and L. Cordeiro. 2004. Nitrogenfixing and vesicular-arbuscular mycorrhizal symbioses in some tropical legume trees of tribe Mimoseae. For. Ecol. Mgt. 196:275-285.

Pejchar, L. and D.M. Press. 2006. Achieving conservation objectives through production forestry: The case of Acacia koa on Hawaii Island. Environ. Sci. Policy 9:439-447.

Rice, W.A. and P.E. Olsen. 1993. Root nodule bacteria and nitrogen fixation, p. 303-317. In: Carter, M.R. (ed.). Soil sampling and methods of analysis. CRC Press, Boca Raton, FL.

Röhm, M. and D. Werner. 1991. Nitrate levels affect the development of the black locustRhizobium symbiosis. Trees 5:227-231.

Scott, J.M., S. Mountainspring, F.L. Ramsey, and C.B. Kepler. 1986. Forest bird communities of the Hawaiian Islands: Their dynamics, ecology, and conservation. Studies Avian Biol. 9:1-431.

Scowcroft, P.G., J.E. Haraguchi, and N.V. Hue. 2004. Reforestation and topography affect montane soil properties, nitrogen pools, and nitrogen transformations in Hawaii. Soil Sci. Soc. Amer. J. 68:959-968.

Scowcroft, P.G. and J. Jeffrey. 1999. Potential significance of frost, topographic relief, and Acacia koa stands to restoration of mesic Hawaiian forests on abandoned rangeland. For. Ecol. Mgt. 114:447-458.

South, D.B. and R.J. Mitchell. 1999. Determining the 'optimum' slash pine seedling size for use with four levels of vegetation management on a flatwoods site in Georgia, USA. Can. J. For. Res. 29:1039-1046.

Thrall, P.H., J.J. Burdon, and M.J. Woods. 2000. Variation in the effectiveness of symbiotic associations between native rhizobia and temperate Australian legumes: Interactions within and between genera. J. Appl. Ecol. 37:52-65.
Thrall, P.H., D.A. Millson, A.C. Jeavons, M. Waayers, G.R. Harvey, D.J. Bagnall, and J. Brockwell. 2005. Seed inoculation with effective root-nodule bacteria enhances revegetation success. J. Appl. Ecol. 42:740-751.

Valladares, F., P. Villar-Salvador, S. Domínguez, M. Fernández-Pascual, J.L. Peñuelas, and F.I. Pugnaire. 2002. Enhancing the early performance of the leguminous shrub Retama sphaerocarpa (L.) Boiss.: Fertilisation versus Rhizobium inoculation. Plant Soil 240:253262.

Villar-Salvador, P., F. Valladares, S. DomínguezLerena, B. Ruiz-Díez, M. Fernández-Pascual, A. Delgado, and J.L. Peñuelas. 2008. Functional traits related to seedling performance in the Mediterranean leguminous shrub Retama sphaerocarpa: Insights from a provenance, fertilization, and rhizobial inoculation study. Environ. Exp. Bot. 64:145-154.

Vitousek, P.M. and H. Farrington. 1997. Nutrient limitation and soil development: Experimental test of a biogeochemical theory. Biogeochemistry 37:63-75.

Walters, G.A. 1981. Why Hawaii is changing to the dibble-tube system of forestation. J. For. 79:743-745.

Wilkinson, K.M. and C.R. Elevitch. 2003. Growing koa: A Hawaiian legacy tree. Permanent Agriculture Resources, Holualoa, HI.

Woldemeskel, E. and F.L. Sinclair. 1998. Variations in seedling growth, nodulation and nitrogen fixation of Acacia nilotica inoculated with eight rhizobial strains. For. Ecol. Mgt. 104: 239-247.

Woomer, P., P.W. Singleton, and B.B. Bohlool. 1988. Ecological indicators of native rhizobia in tropical soils. Appl. Environ. Microbiol. 54:1112-1116.

Yanagida, J.F., J.B. Friday, P. Illukpitiya, R.J. Mamiit, and Q. Edwards. 2004. Economic value of Hawaii's forest industry in 2001. Univ. of Hawai'i Coop. Exten. Serv. Pub. EI-7. 